\title{
Temporal and spatial variations in spectral reflectance and characteristics of surface dust on Gulkana Glacier, Alaska Range
}

\author{
Nozomu TAKEUCHI \\ Department of Earth Sciences, Graduate School of Science, Chiba University, 1-33, Yayoi-cho, Inage-ku, Chiba 263-8522, \\ Japan \\ E-mail: ntakeuch@faculty.chiba-u.jp
}

\begin{abstract}
Spectral reflectances in the visible to near-infrared wavelength range $(350-1050 \mathrm{~nm})$ were measured on the surface of Gulkana Glacier, Alaska Range, Alaska, USA, at six different elevations from May to September 2001. The measurements showed variable spectral reflectances on the glacier surface, and the spectra changed over time and elevation. The spectra in May were those of a typical wet snow surface: the reflectance ranged approximately from 0.4 to 0.8 , and generally decreased as the wavelength increased. As snowmelt proceeded, the reflectance gradually fell, and specific absorptions appeared in the spectrum at wavelength ranges of $400-600$ and $670-680 \mathrm{~nm}$, corresponding to a red snow surface due to snow algal bloom. As the ice surface was exposed, the spectrum finally shifted to a lower (0.1-0.4) and flat reflectance curve, typical of an ice surface contaminated with dust. Analyses of the dust on the glacier surface showed that its quantity and characteristics changed spatially and seasonally and were correlated with spectral albedo. The results showed that the temporal and spatial variations in spectral reflectance on this glacier are due not only to physical properties of the glacier surface, but also to biogenic materials on the surface (e.g red-colored snow algal cells and cryoconite).
\end{abstract}

\section{BACKGROUND AND INTRODUCTION}

The surface albedo of glaciers is an important factor affecting glacial heat budget and mass balance. A lower-albedo surface absorbs more solar radiation, resulting in more snowand ice melt, while a higher-albedo surface reflects more solar radiation, resulting in less melt. The surface albedo varies spatially and temporally on a glacier, and also differs from glacier to glacier (Cutler and Munro, 1996; Brock and others, 2000; Jonsell and others, 2003; Klok and others, 2003). In order to develop glacial mass-balance models, it is important to know the temporal and spatial variation of the albedo and to understand how variations are determined.

Major factors affecting glacier surface albedo are the physical properties and impurities of snow and ice (Paterson, 1994). For example, fresh new snow is highest in albedo. The snow albedo decreases as snowmelt proceeds, and is lowest when the ablation ice surface becomes exposed. Impurities in snow and ice (e.g. wind-blown mineral dust and soot) also substantially affect glacier surface albedo. Recent studies have revealed that impurities in snow and ice are derived not only from wind-blown particles, but also from biological activity on the glacier surface. There are diverse organisms living on the glacier surface (e.g. snow algae, insects, ice worms, protozoa and bacteria). They are specialized species that have adapted to cold environments and spend their whole lives on glaciers (Kohshima, 1987; Hoham and Duval, 2001). Surface dust contains products such as the organisms themselves, their dead remains, and decomposed organic matter (humic substances). Since these organic particles have relatively small single-scattering albedo, yet are large in volume, they are optically effective on the surface albedo (Takeuchi and others, 2001; Takeuchi, 2002b). Such biogenic surface dust on glacial ice is known as cryoconite, and it exerts a significant impact on the albedo of the ablation surface on some glaciers (Kohshima and others, 1993; Takeuchi and others, 2001, 2005; Takeuchi, 2002b). Red snow algae are also known to bloom on glacier snow surfaces and to affect surface albedo (e.g. Hall and others, 1990). They are unicellular and spherical cells approximately $20 \mu \mathrm{m}$ in diameter and grow in a water film of melting snowpack (Erbe and others, 2003).

The quantity and characteristics of these impurities on a glacier vary spatially and temporally. For example, windblown dust deposit on a glacier surface is seasonal (e.g. usually spring in Asian glaciers (Wake and others, 1994)), and snow-algae bloom on a glacier surface is seasonal and elevation-dependent (e.g. summer near the snowline on one Alaskan glacier (Takeuchi, 2001)). However, temporal and spatial variations of impurities on glacier surfaces and how the variations affect the surface albedo are still not well understood.

Spectral reflectance is valuable for examining the variation of surface albedo on a glacier. The spectra vary with physical properties of the glacier surface, and also with the quantity and optical characteristics of impurities (Warren and Wiscombe, 1980; Warren, 1982; Painter and others, 2001; Takeuchi, 2002a). Spectral reflectance is also important information for determining the glacier surface albedo by remote sensing (Cutler and Munro, 1996; Dozier and Painter, 2004).

In this study, spectral reflectances $(350-1050 \mathrm{~nm}$ in wavelength) of the glacier surface were measured on Gulkana Glacier, Alaska Range, Alaska, USA, at six different elevations from May to September 2001. The amounts of surface dust and their organic matter content at each study site were also measured. The temporal and spatial variations in spectral reflectance are discussed in terms of physical properties and impurities of snow and ice.

\section{STUDY SITE AND METHODS}

The investigations were carried out in 2001 on Gulkana Glacier, located in the central Alaska Range (Figs 1 and 2). The glacier flows west to south from Icefall Peak 


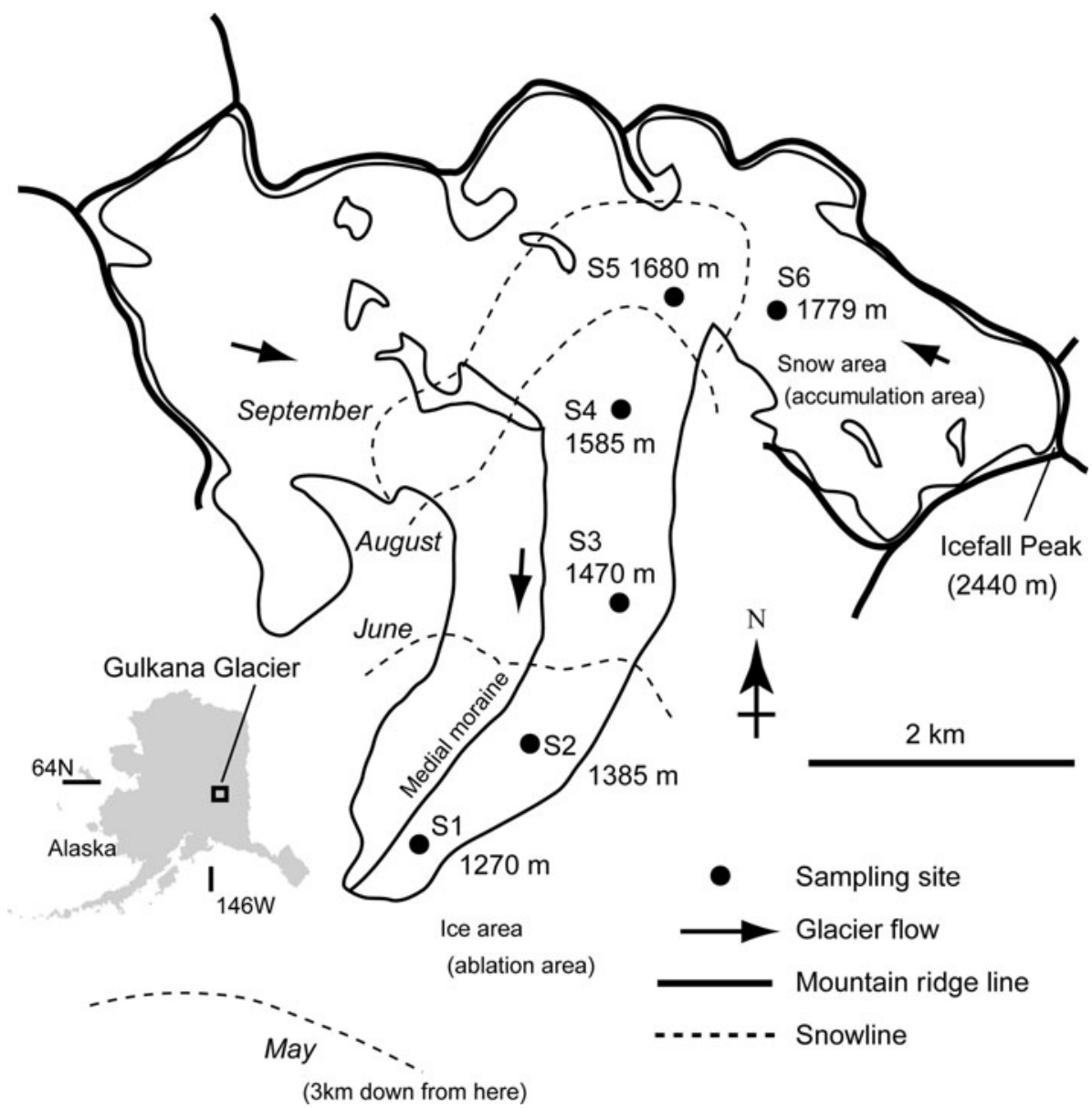

Fig. 1. Map of Gulkana Glacier in the Alaska Range, showing locations of snowline and sampling sites on the glacier surface.

( 2440 m a.s.l.) to the terminus at $\sim 1220$ m a.s.l. The glacier is easily accessible from the Richardson Highway and has been monitored for several decades by the University of Alaska and the United States Geological Survey (USGS) (Josberger and others, 2007). It has generally been receding during the last 50 years and lost $11 \pm 5 \mathrm{~m}$ ice thickness averaged over the whole glacier between 1954 and 1993
(Dowdeswell and others, 1997). Its length and area are approximately $4 \mathrm{~km}$ and $21.8 \mathrm{~km}^{2}$ respectively. The equilibrium line of the glacial mass balance in 2001 was $\sim 1790$ m a.s.I. (USGS measurement; http://ak.water.usgs.gov/ glaciology/gulkana/).

Prior to this research, fieldwork had been carried out in August 2000 to investigate the characteristics of surface dust

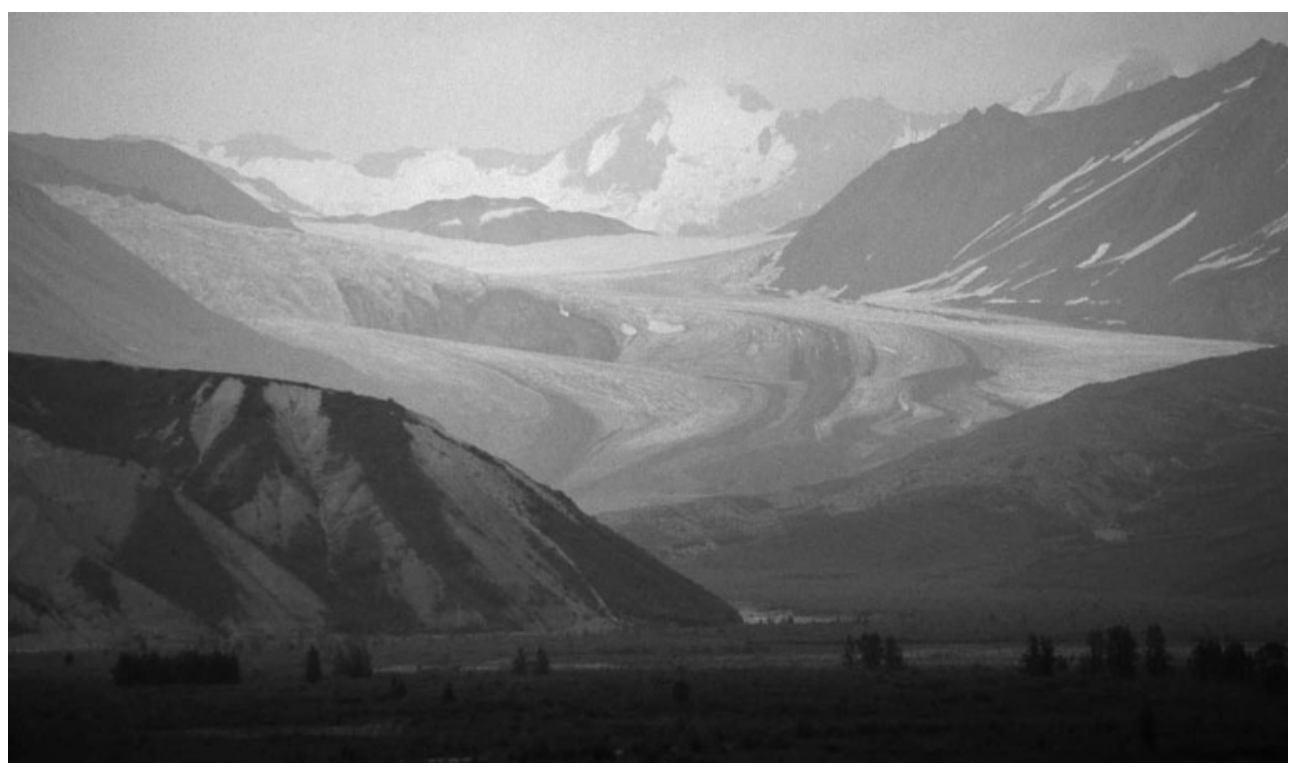

Fig. 2. View of Gulkana Glacier from $\sim 8 \mathrm{~km}$ from the terminus (August 2001). 
and algal communities on the glacier. The investigation revealed that surface dust on the glacier was not simply wind-blown mineral dust, but biogenic cryoconite, which contains abundant microbes and organic matter. Amounts of surface dust and the level of organic matter of the dust varied with elevation (Takeuchi, 2002b). The snow algal community also varied with altitude on the glacier (Takeuchi, 2001). This paper focuses on temporal variations in spectral reflectance and the amount of surface dust, and is based on fieldwork during the 2001 melt season.

Spectral reflectance measurement and ice/snow sampling were carried out four times from spring to late summer 2001 at six locations between 1270 and $1770 \mathrm{ma.s.I.} \mathrm{(S1-S6;}$ Fig. 1). The four periods of fieldwork were May (28 May-1 June), June (25-29 June), August (6-10 August) and September (3-7 September).

The spectral reflectance at each site was measured with spectrometers with a small field-of-view (FOV) foreoptic. A model 2703 spectrometer, manufactured by Abe Sekkei Co., Japan, was used for the first fieldwork in May, and a FieldSpec Pro visible/near-infrared (VNIR) spectrometer, manufactured by Analytical Spectral Devices, USA, was used for the other three field study periods. The model 2703 spectrometer has a $2^{\circ}$ FOV foreoptic. It is small and lightweight, but showed much lower wavelength resolution in than the FieldSpec Pro VNIR spectrometer. It can measure radiation at wavelengths of 400, 450, 500, 550, 550, 600, 650, 700, 750, 850, 950 and $1050 \mathrm{~nm}$. The FieldSpec Pro VNIR, on the other hand, has a $3^{\circ} \mathrm{FOV}$ foreoptic and is heavier and larger but can measure radiation with 512 channels of wavelength 350-1050 nm (approximately every $1.4 \mathrm{~nm}$, with a spectral resolution of $3 \mathrm{~nm}$ at $700 \mathrm{~nm}$ ). This spectrometer has been radiometrically calibrated by the manufacturer. The measured irradiances of the two spectrometers were compared, and the output of the model 2703 spectrometer was calibrated based on that of the FieldSpec spectrometer.

The spectral reflectance measured in this study was a hemispherical-directional reflectance factor (HDRF). The HDRF is given by the ratio of the reflected radiance from a target surface area in a single direction to the irradiance from the entire hemisphere to the area (e.g. Schaepman-Strub and others, 2006). The reflected radiance in the nadir direction was measured $30 \mathrm{~cm}$ above the target surface with a spectrometer. The radiance reflected by a Lambertian white reference plate (Spectralon $12.7 \mathrm{~cm} \times 12.7 \mathrm{~cm}$, Labsphere, USA) was then measured in the nadir direction with a spectrometer. This radiance includes both direct and diffuse irradiances from the entire hemisphere to the target surface. The measurements were carried out within 3 hours of local solar noon under cloud-free conditions. The spectral reflectance was obtained from the ratio of the measured radiance of the target surface to that of the white reference plate at each wavelength. The spectrally integrated albedo was calculated from the total reflected radiance in the measured wavelength range $(350-1050 \mathrm{~nm})$ of the target surface and that of the white reference plate. Mean spectral reflectance and integrated albedo were obtained from values of five different surfaces at each site. There was a lack of data at four sites in May (S1, S3, S5 and S6) and one site in September (S6) due to the limited time available for the fieldwork.

In order to measure the amount of glacier surface dust and its organic matter content, ice/snow from the surface layer was collected with a stainless-steel scoop in an area of approximately $15 \mathrm{~cm} \times 15 \mathrm{~cm}$ to a depth of $1-3 \mathrm{~cm}$. This depth is sufficient to collect surface dust affecting the surface albedo because all the sample collections were done during the melting season, when dust contained in snow or ice concentrates at the surface layer as melting proceeds. Collection areas on the surface were measured to calculate the amount of dust per unit area. The collected samples were melted and preserved as a $3 \%$ formalin solution in $125 \mathrm{~mL}$ clean polyethylene bottles to fix biological activity. All samples were transported by car to the International Arctic Research Center, University of Alaska Fairbanks (UAF), for analysis. In the laboratory, the samples were dried $\left(65^{\circ} \mathrm{C}\right.$, 24 hours) in pre-weighed crucibles. The amount of dust per unit area of the glacier was obtained based on measurements of the dry weight and the sampling area. The dried samples were then combusted for 1 hour at $1000^{\circ} \mathrm{C}$ in an electric furnace and reweighed. The amount of organic matter was obtained from the difference in weight of the dried and combusted samples. After combustion, only mineral particles remained.

\section{RESULTS}

\subsection{Temporal and spatial variations in spectral reflectance}

Measurements show variable spectral reflectance on the glacier surface (Fig. 3). The spectral curves varied spatially and temporally. Reflectance generally decreased from May to September in the entire wavelength range, and also generally decreased with elevation.

In May, the spectra showed generally higher reflectance and no significant variance across study sites (Fig. 3a). At this time, the entire glacier surface including the study sites (S2 and S4) was covered with winter snow. The integrated albedo at S2 and S4 was 0.726 and 0.727 respectively. Spectra at both sites showed that reflectance in the wavelength range $400-800 \mathrm{~nm}$ was generally high (0.7) and decreased to 0.4 as wavelength increased.

In June, the spectra varied significantly across the study sites (Fig. 3b). The snowline was located between S2 and S3, so the ice surface was exposed at the lowest two sites (S1 and S2). At the upper sites (S4-S6), the spectra were similar to those observed in May: reflectance was generally high and decreased as wavelength increased. At S3, the spectrum was generally lower than at the upper sites and showed distinctive features: there were two absorptions at wavelength ranges $400-600$ and $670-680 \mathrm{~nm}$ respectively. At the lowest two ice surfaces (sites S1 and S2), the spectra showed generally lower and flatter curves than at the upper sites.

In August, spectral reflectances generally decreased and varied across the study sites (Fig. 3c). The snowline rose to S4-S5 in this month, so the ice surface was exposed at the lowest four sites (S1-S4). The spectra at the highest two sites were distinctive curves similar to those observed at S3 in June. They showed absorption features in the ranges 400-600 and $670-680 \mathrm{~nm}$. The spectra at the lowest four sites showed lower, flatter curves. Two of the spectra (sites S2 and S3) showed slightly higher reflectance than at S1 and S4 at wavelengths of $350-850 \mathrm{~nm}$.

In September, the spectra at all sites were generally lower and flatter than in the other months studied (Fig. 3d). The snowline was located above S5, so all the study sites (S1-S5) were ice surfaces. The integrated albedos ranged from 0.251 to 0.343 . The spectra varied slightly across the study sites: at 

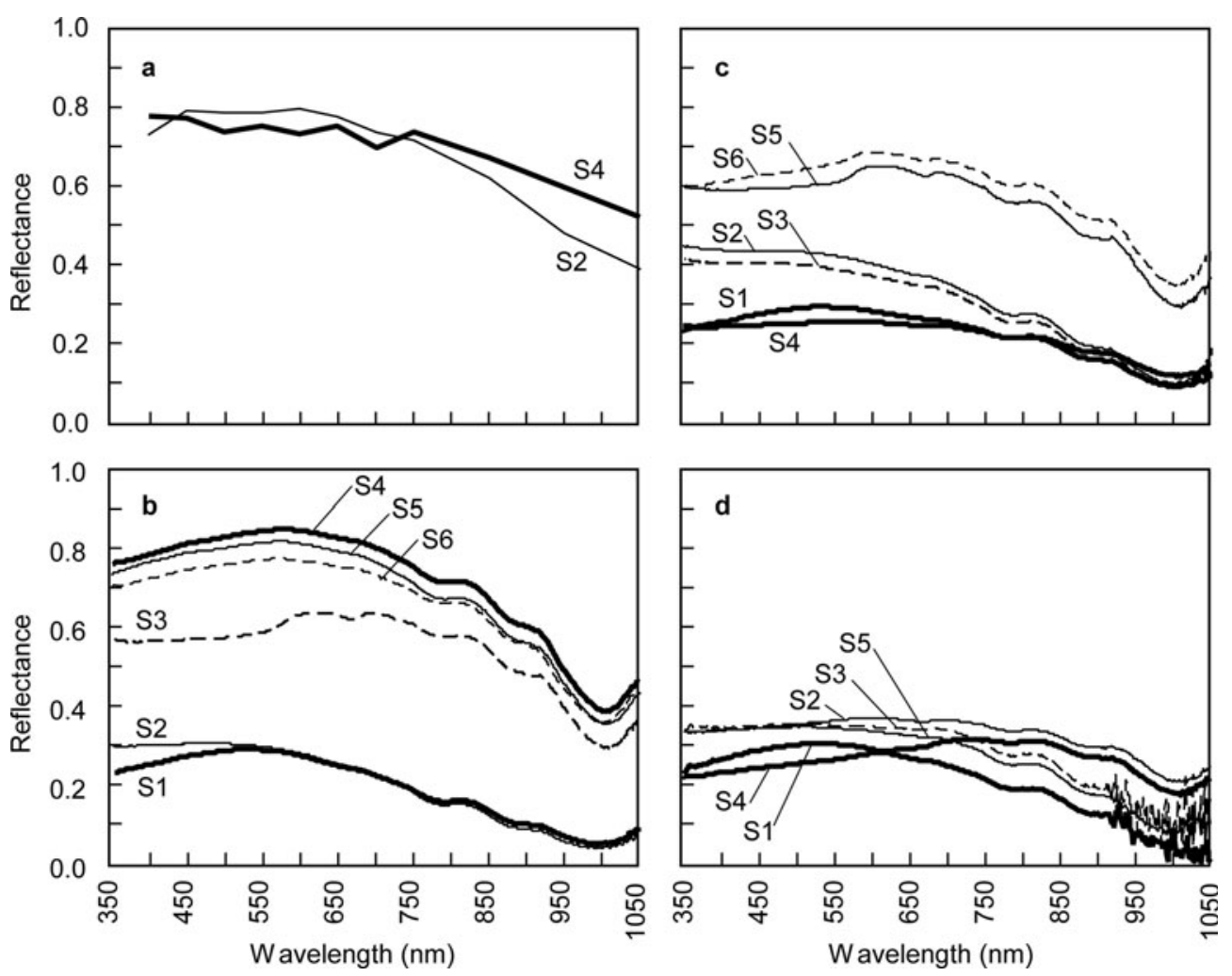

Fig. 3. Spectral reflectances of surfaces at six study sites on Gulkana Glacier in (a) May, (b) June, (c) August and (d) September. The curves indicate mean surface reflectance of five surfaces at each site.

S1 the spectrum was lower than at the other sites, and S4 exhibited lower reflectance at wavelengths of $400-700 \mathrm{~nm}$.

\subsection{Variations in characteristics of surface dust in snow and ice}

The amounts of surface dust (cryoconite) measured by sampling of snow and ice on the glacier also significantly varied across seasons and study sites (Fig. 4). These amounts were generally larger on ice surfaces than snow surfaces, ranging from 8.10 to $60.8 \mathrm{~g} \mathrm{~m}^{-2}$, against $0.02-4.34 \mathrm{~g} \mathrm{~m}^{-2}$ on snow surfaces.

In May, the amounts of surface dust were small and evidenced no significant difference among the study sites (Fig. 4a). In June, they were greatest at the lowest two sites (S1 and S2), where the ice surface was exposed, and least at the highest four sites (S3-S6), where the surface was still snow (Fig. 4b). In August, the snowline rose to S4-S5, and the dust amounts were greatest at the lowest four sites (S1-S4; Fig. 4c). The largest dust amount was at S1. The largest amount on the snow surface occurred in August at S5 $\left(4.34 \mathrm{~g} \mathrm{~m}^{-2}\right)$. In September, all the study sites (S1-S5) were ice surfaces, and the amounts ranged from 8.01 to 38.5 (Fig. 4d).

The variability in amount of organic matter showed a pattern similar to that for surface dust (Fig. 5). Amounts of organic matter were generally greater on the ice surfaces than on the snow surface. Ice surface amounts ranged from 0.61 to $3.86 \mathrm{~g} \mathrm{~m}^{-2}$, while snow surface amounts ranged from 0.00 to $0.60 \mathrm{~g} \mathrm{~m}^{-2}$. The largest amount of organic matter on the ice surface occurred at S5 in September $\left(3.86 \mathrm{~g} \mathrm{~m}^{-2}\right)$, and the largest on the snow surface occurred at S5 in August $\left(0.60 \mathrm{~g} \mathrm{~m}^{-2}\right)$. It appears that organic matter was invariant on the ice surface through the seasons, while it increased significantly on the snow surface at S5 from June to August (0.13 vs $\left.0.60 \mathrm{~g} \mathrm{~m}^{-2}\right)$.
Variations in the ratio of organic matter to total dry weight of surface dust showed a different pattern from variations in the amounts of surface dust or organic matter (Fig. 6). The percentage ranged from $2.9 \%$ to $8.8 \%$ on the ice surface and from $4.2 \%$ to $13.5 \%$ on the snow surfaces. The lowest percentage occurred on the ice surface at S1 in August $(2.9 \%)$, and the highest on the snow surface at S5 in August $(13.5 \%)$. On the ice surfaces, the percentages were generally low at the lowest site (S1), and increased with elevation until S3. Temporal change in the percentage was not significant on the ice surfaces. On the snow surfaces, the higher percentage occurred at the lowest site in the snow area (i.e. S3 in June, S5 in August).

\section{DISCUSSION}

\subsection{Three types of spectrum on the glacier surface}

The various spectral reflectances observed on the glacier surface can be classified into three major types. Type $A$ is the spectrum with higher reflectance $(0.7-0.9)$ in the range $350-800 \mathrm{~nm}$. It includes spectra at S2 and S4 in May, and S4, S5 and S6 in June. The type B spectrum has distinctive absorbance features in the wavelength ranges 400-600 and 670-680 nm. This type includes S3 in June and S5 and S6 in August. The type $\mathrm{C}$ spectrum generally shows low reflectance in the visible wavelengths $(0.1-0.3)$. This type includes S1 and S2 in June, S1-S4 in August and S1-S5 in September.

The three types of spectra correspond to different physical conditions on the glacier surface and characteristics of impurities in snow and ice. All type A spectra were observed on the snow surface and coincided with those of the wet snow surface, as previously reported (Warren, 1982; Zeng 

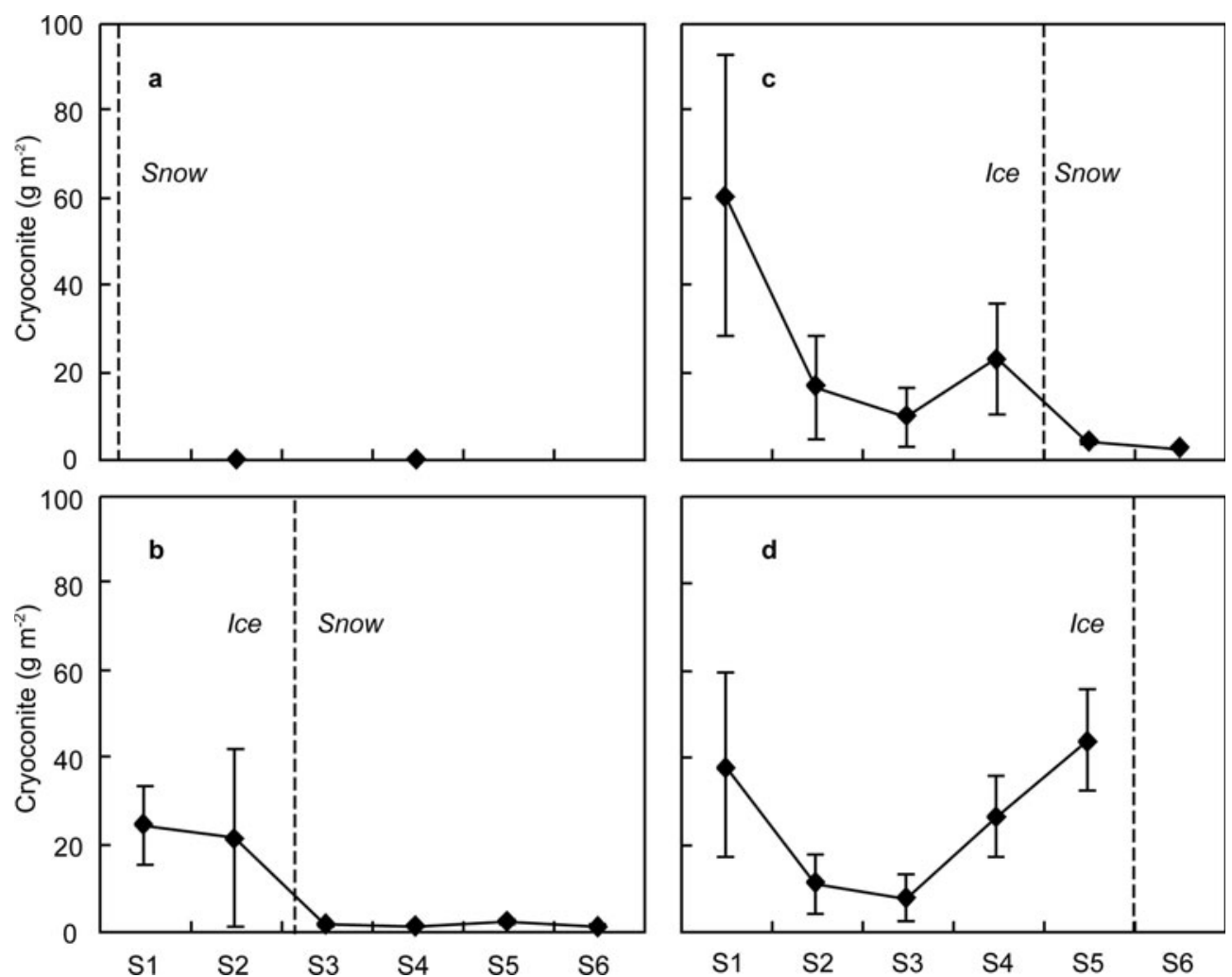

Fig. 4. Mean amount of surface dust (cryoconite) $\left(\mathrm{g} \mathrm{m}^{-2}\right.$ dry weight) on the surface of Gulkana Glacier in (a) May, (b) June, (c) August and (d) September. Error bar shows standard deviation.

and others, 1984). Similarly, type C spectra were observed on the ice surface, coinciding with spectra of bare ice surfaces (Zeng and others, 1984). The type B spectrum is likely to be of a red snow surface due to bloom of red- colored snow algae. The absorbance features of the type B spectrum coincide with those of red algal snow, i.e. the $400-600 \mathrm{~nm}$ range was mainly due to carotinoids, while the $670-680 \mathrm{~nm}$ range was due to chlorophylls (e.g. Painter and
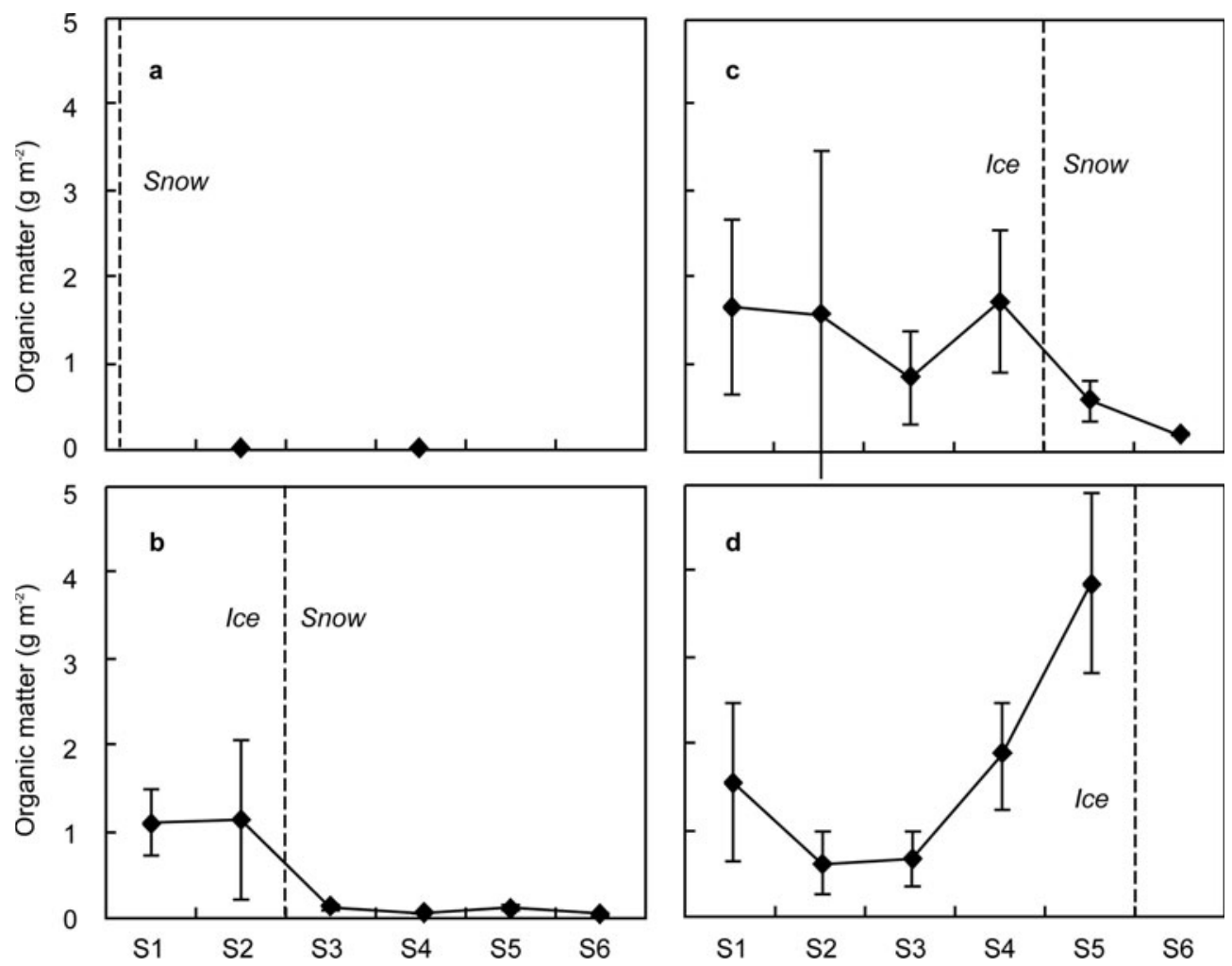

Fig. 5. Mean amount of organic matter ( $\mathrm{g} \mathrm{m}^{-2}$ dry weight) on the surface of Gulkana Glacier in (a) May, (b) June, (c) August and (d) September. Error bar shows standard deviation. 

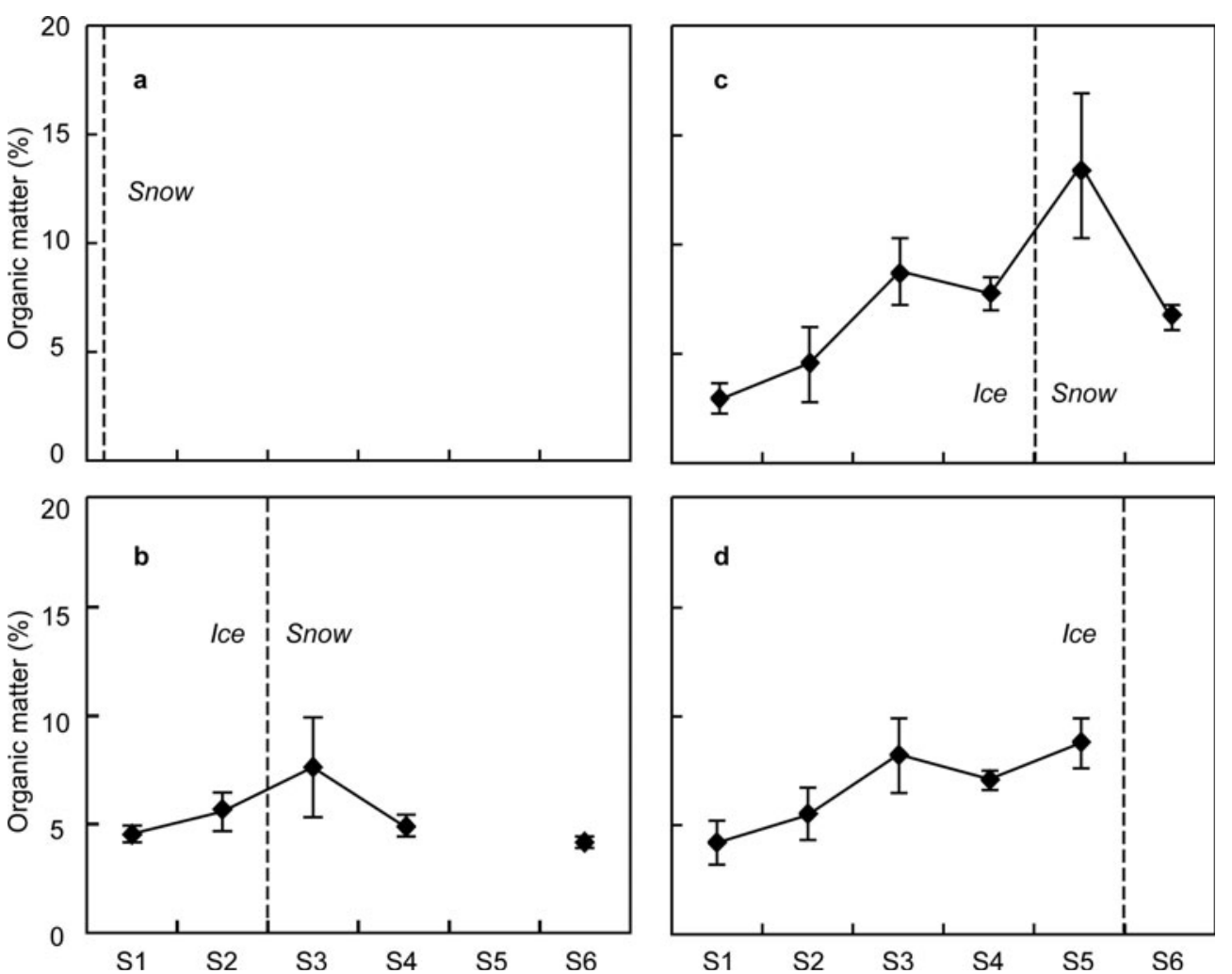

Fig. 6. Fraction of organic matter in cryoconite on Gulkana Glacier in (a) May, (b) June, (c) August and (d) September. Data for S2 and S4 in May and S5 in June are not shown because analyzed organic matter is too small to calculate percentage. Error bar shows standard deviation.

others, 2001). Thus, type A, B and C spectra are those of white wet snow, red algal snow and bare ice surfaces respectively.

The spectral reflectances at S5 from June to September showed a typical seasonal succession of the three types of spectra (Fig. 7). In June, the spectrum was type A, indicating that the glacier surface was white wet snow. In August, it shifted to type $B$, indicating that a bloom of red snow algae occurred on the snow surface. In September, it decreased and became type $\mathrm{C}$, indicating the snow had finally

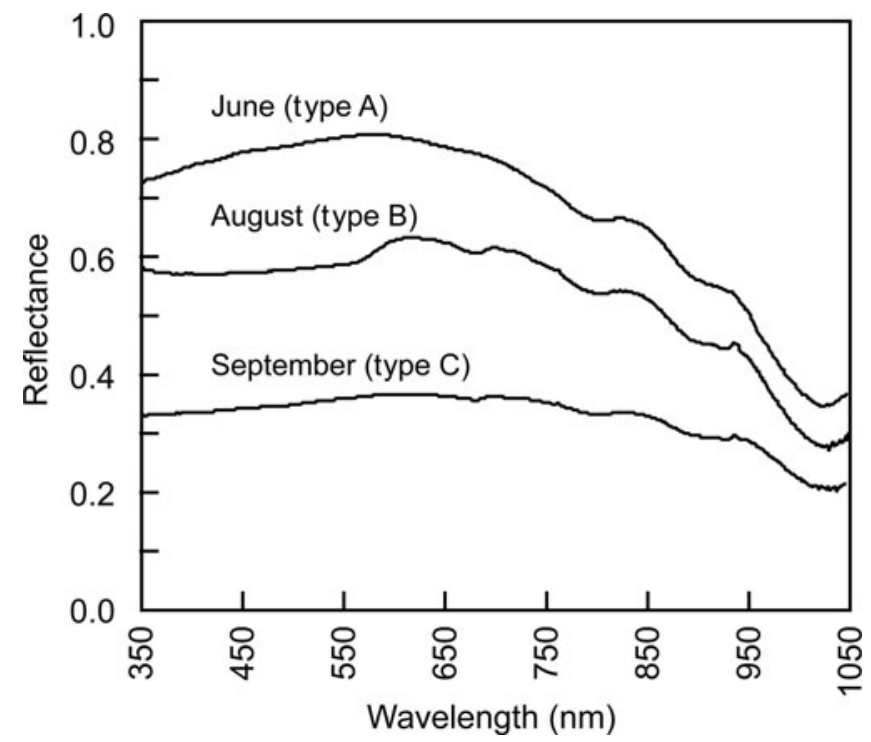

Fig. 7. Change of spectral reflectance at S5 from June to September. disappeared and the ice surface was fully exposed. The shift from type $A$ to type $B$ is due to a biological process, a snow algal bloom on the snow surface.

Each spectral type showed a distinctive range of integrated albedo. The albedo for type $A$ ranged from 0.65 to 0.80 , that of type B from 0.50 to 0.65 and that of type $\mathrm{C}$ from 0.20 to 0.40 . Figure 8 shows the seasonal changes of the integrated albedo at each study site. In May, albedo values at S1, S3, S5 and S6 were not measured. In Figure 8 they are assumed to be similar to those at S2 and S4 (0.73) because the entire glacier surface was covered with wet snow and there was no significant difference in the observable surface conditions from S1 up to S4. Snowalgae bloom was also unlikely to occur in this month since no algal bloom was observed from S1 to S4 and algal biomass on the snow surface decreased as altitude increased (Takeuchi, 2001). However, it is possible that albedo at the highest-elevation sites (S5 and S6) is slightly higher than at S2 and S4 since dust is less concentrated at the surface layer and snow grain size is smaller due to lower air temperature. In Figure 8, the integrated albedo decreased gradually between spring and late summer at each site. This shift in spectrum type at lower sites proceeded to upper sites of the glacier. The albedo at all sites finally decreased to type $\mathrm{C}$ in September. The figure shows that the type B spectrum (algal spectrum) always occurred just prior to the appearance of the ice surface, probably due to the abundant meltwater content of the snow, which is a requirement for algal blooms. Although type B spectra were not directly observed at S1, S2 and S4 in this study, they are likely to occur in early June at S1 and S2, and in July at S4. Type B spectra seemed to move upward as the snowline rose on the glacier. 


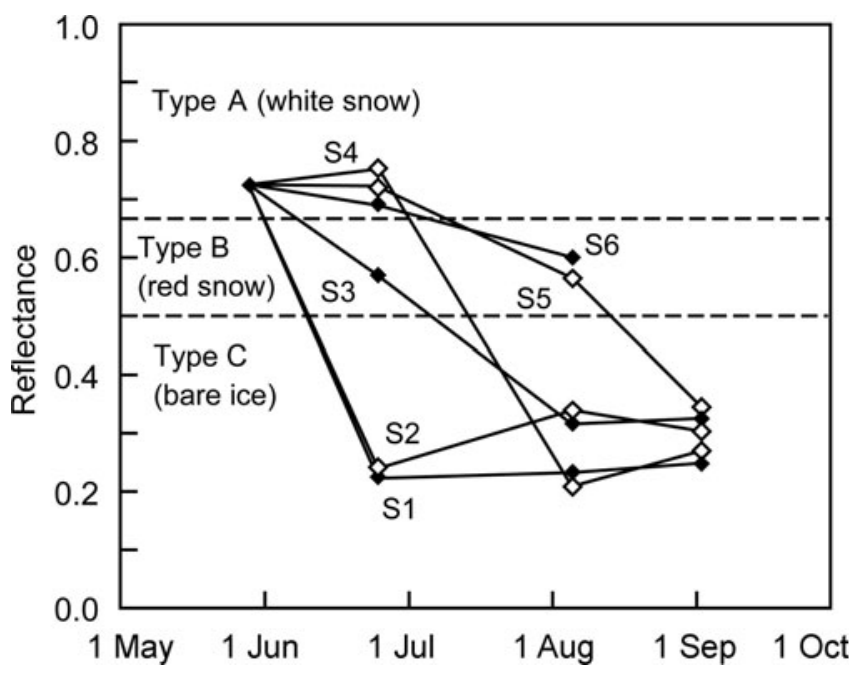

Fig. 8. Change of mean integrated albedo at each study site from May to September.

\subsection{Variations in amounts of surface dust and their effect on reflectances}

Dust on the snow surface gradually increased from May to August, ranging from 0.02 to $0.30 \mathrm{~g} \mathrm{~m}^{-2}$ in May, 1.19 to $2.38 \mathrm{~g} \mathrm{~m}^{-2}$ in June, and 2.95 to $4.34 \mathrm{~g} \mathrm{~m}^{-2}$ in August (Fig. 9). A statistical test (one-way analysis of variance (ANOVA)) showed that this seasonal increase is significant $(F=6.04$, $P=0.0070<0.01)$. Figure 9 shows that both mineral and organic content in the dust increased from May to August, probably due to condensation of dust in snow by melting, deposition of wind-blown dust, and/or growth of snow algae on the snow surface.

The correlation coefficient between integrated surface albedo and dust amount on all measured snow surfaces showed a significant negative correlation $(r=-0.425$, $P=0.012<0.05)$, suggesting that dust substantially reduces the albedo of the snow surface. There were also significant correlations between the albedo and the mass fraction of mineral particles in the dust (Fig. $10 ; r=-0.408, n=34$, $P=0.017<0.05)$, and between the albedo and the mass fraction of organic matter in the dust (Fig. 10; $r=-0.520$, $n=34, P=0.0016<0.01)$. Although the mass fraction of organic matter was much smaller than that of mineral particles $(4.19-13.52 \%$ for organic matter content), the correlation between organic matter and surface albedo was stronger than between mineral particles and albedo $(-0.520$ vs -0.408). This suggests that organic matter in the dust is more effective than mineral particles in reducing albedo. Since the density of organic matter is generally lower than that of mineral particles, the particle volume is much larger than that of mineral particles, and thus likely to be more effective in reducing surface albedo. The organic matter in the dust consisted mainly of snow algal cells as suggested by the type B spectral reflectances. Therefore, snow algal bloom is likely to be the predominant factor influencing snow-surface albedo on this glacier.

On the ice surface, the spatial variation in the amounts of surface dust differed significantly across elevations, although the seasonal variation was not significant. A statistical analysis (one-way ANOVA) of the seasonal variation (June-September) in dust amounts at S1 and S2 showed

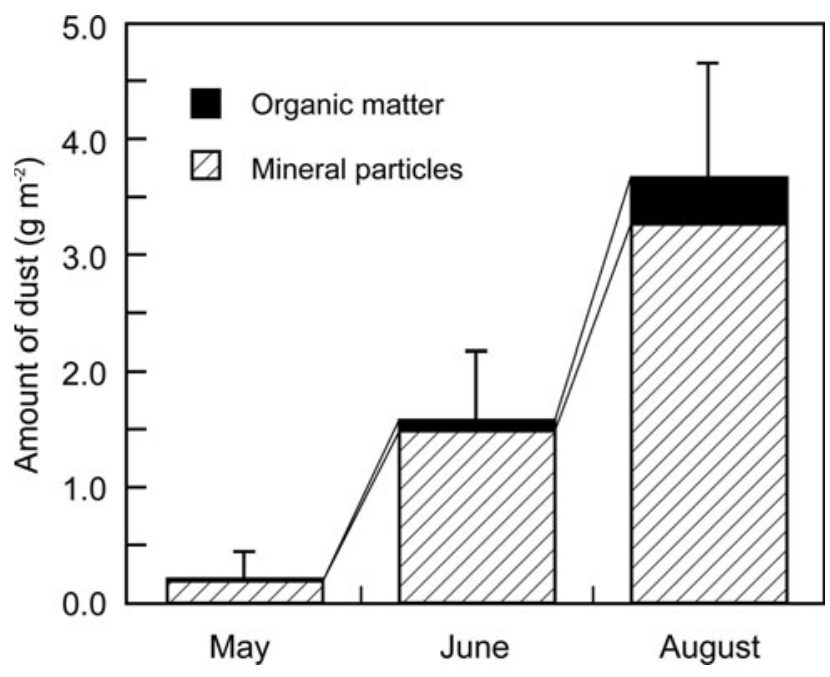

Fig. 9. Change of mass fraction of organic matter and mineral particles of the dust in the snow area of Gulkana Glacier.
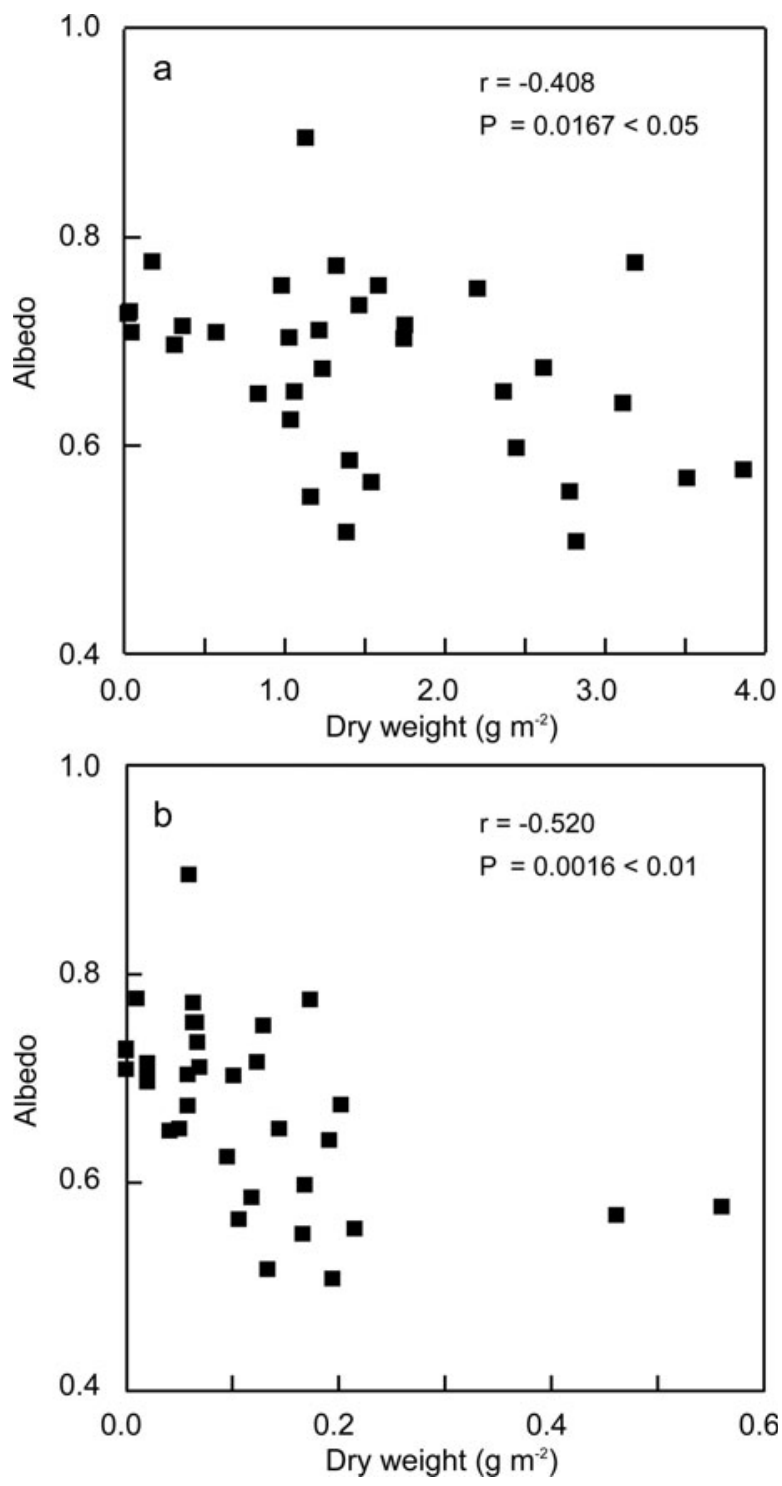

Fig. 10. Relationships between (a) the albedo and the mass fraction of mineral particles in the dust, and (b) the albedo and the mass fraction of organic matter in the dust. 
no significant variation at either site (S1: $F=3.24$, $P=0.075>0.05 ;$ S2: $F=0.999, P=0.39>0.05)$. However, statistical analyses of the spatial variation of dust amounts showed significant differences among the study sites. For example, variations in the dust amounts from S1 to S4 in August, and from S1 to S5 in September were significant (one-way ANOVA, August: $F=7.06, P=0.003<0.05$; September: $F=8.61, P=0.0003<0.05)$. This variation showed that dust amounts at S1, S4 and S5 were larger than at S2 and S3. Compared with the variation in the integrated albedo, larger amounts of surface dust at S1 and S4 coincide with relatively lower albedo (S1: 0.222-0.251; S4: $0.211-$ 0.268 ) and the smaller amounts at S2 and S3 coincide with higher albedo (S2: 0.233-0.338; S3: 0.318-0.324). Thus, the amounts of surface dust on the ice surface account for the variation in surface albedo. Although some albedo values (0.233 at S2 in June and 0.343 at S5 in September) were inconsistent with the dust amounts, these cases may be due to the effect of surface ice structure such as weathering ice crust (e.g. Jonsell and others, 2003).

There was a significant difference in the fraction of organic matter in the ice-surface dust between the lowest site (S1) and the middle sites (S4 and S5), where the dust amounts were relatively larger than at other sites in the ice area. The fraction of organic matter in the surface dust was two to three times higher at the middle sites than at the lowest site (S4 and S5: 7.1-8.8\%; S1: 2.9-4.6\%). This different composition in the two areas indicates a difference in the main source of impurities on the glacier surface. The lower organic-matter fraction in the lowest part of the glacier is probably due to a larger supply of wind-blown mineral particles, and/or to less snow algae production (Takeuchi, 2002b). Snow algae biomass is also largest in the middle part of the glacier (Takeuchi, 2001), suggesting that this area is biologically productive. Thus, the albedo reduction in the lower area of the glacier is likely due mainly to wind-blown mineral impurities, while that in the middle area is likely due mainly to biogenic organic matter.

A microscopic study of dust (Takeuchi, 2002b) revealed that the biogenic impurities on the ice surface are not only snow algal cells, but also dark-colored cryoconite granules. These are a cluster of mineral particles, filamentous cyanobacteria, dead bodies of microbes, and dark-colored humic substances. The spectral curves observed on the ice surfaces were generally flat and did not show apparent chlorophyll a absorption $(680 \mathrm{~nm})$ of snow algae. This suggests that the dark-colored cryoconite granules generate higher ice surface albedo than snow algal cells. Thus, amounts of cryoconite granules are likely to be the predominant factor affecting ice surface albedo, particularly in the middle part of the glacier where the organic matter is largely contained in the surface dust.

The results showed that spectral reflectance of the surface of this glacier varied spatially and seasonally, and was altered not only by physical processes, but also by the biological process on the glacier. Parameterization of surface albedo variation is important for glacial mass-balance models and has been developed in some glaciers (e.g. Brock and others, 2000), but no model has involved the biological effect on surface albedo. Red algal snow has been reported on many snowfields and glaciers worldwide. A remote-sensing study has revealed that red-colored snow algae covered a wide range of an Alaskan icefield (the Harding Icefield), which is likely to significantly affect snow surface albedo (Takeuchi and others, 2006). Furthermore, cryoconite is common on many glaciers, particularly in Asia (e.g. Takeuchi and others, 2005). Therefore, a biological effect on glacier surface albedo must be considered in terms of its influence on mass balance of these glaciers. Further studies are necessary to quantify the biological effect on the surface albedo and to understand the environmental factors determining biological activity on the glacier.

\section{CONCLUSIONS}

Field investigations on Gulkana Glacier in the melt season May-September 2001 revealed that the spectral reflectances of the glacier surface varied spatially and seasonally. The results showed spectra of a typical wet snow surface in May, changing to spectra with specific absorptions of red snow algae, and finally shifting to a lower and flat reflectance curve of a typical ice surface contaminated with dust. This spectral shift gradually proceeded from the lower to the upper areas of the glacier. Analyses of dust on the glacier surface showed that the quantity and characteristics of the dust also changed spatially and seasonally and were associated with spectral albedo. The variation in the spectra on the snow surface was mainly due to wind-blown dust and snow algae on the snow, while the variation on the ice surface was due to the amounts and properties of cryoconite on the ice. The results showed that the temporal and spatial variations in the spectral reflectance on this glacier are due not only to the physical properties of the glacier surface, but also to the biogenic materials on the surface. A biological effect on glacier surface albedo must thus be considered in terms of its influence on mass balance of these glaciers.

\section{ACKNOWLEDGEMENTS}

I thank S. Akasofu, M. Ikeda and N. Tanaka of the International Arctic Research Center, UAF, for generous support and encouragement, and L. Hansen, L. Leslie, N. Uzuka, S. Kohshima, T. Segawa and J. Uetake for expert field assistance. I also thank two reviewers (T.H. Painter and anonymous) for helpful suggestions that greatly improved the manuscript. The fieldwork and laboratory analyses were funded by a project of Frontier Observational Research for Global Change (funded by the Japan Marine Science and Technology Center), a Grant-in-Aid for Young Scientists (A, No. 18681005) and a Grant-in-Aid for Scientific Research (B, No. 19310020) of the Japan Society for the Promotion of Science (JSPS).

\section{REFERENCES}

Brock, B.W., I.C. Willis and M.J. Sharp. 2000. Measurement and parameterization of albedo variations at Haut Glacier d'Arolla, Switzerland. J. Glaciol., 46(155), 675-688.

Cutler, P.M. and D.S. Munro. 1996. Visible and near-infrared reflectivity during the ablation period on Peyto Glacier, Alberta, Canada. J. Glaciol., 42(141), 333-340.

Dowdeswell, J.A. and 10 others. 1997. The mass balance of circum-Arctic glaciers and recent climate change. Quat. Res., 48(1), 1-14.

Dozier, J. and T.H. Painter. 2004. Multispectral and hyperspectral remote sensing of alpine snow properties. Annu. Rev. Earth Planet. Sci., 32, 465-494.

Erbe, E.F., A. Rango, J. Foster, E.G. Josberger, C. Pooley and W.P. Wergin. 2003. Collecting, shipping, storing, and imaging 
snow crystals and ice grains with low-temperature scanning electron microscopy. Microsc. Res. Techn., 62(1), 19-32.

Hall, D.K., R.A. Bindschadler, J.L. Foster, A.T.C. Chang and H. Siddalingaiah. 1990. Comparison of in situ and satellitederived reflectances of Forbindels Glacier, Greenland. Int. J. Remote Sens., 11(3), 493-504.

Hoham, R.W. and B. Duval. 2001. Microbial ecology of snow and freshwater ice with emphasis on snow algae. In Jones, H.G., J.W. Pomeroy, D.A. Walker and R.W. Hoham, eds. Snow ecology: an interdisciplinary examination of snow-covered ecosystems. Cambridge, Cambridge University Press, 168-228.

Jonsell, U., R. Hock and B. Holmgren. 2003. Spatial and temporal variations in albedo on Storglaciären, Sweden. J. Glaciol., 49(164), 59-68.

Josberger, E.G., W.R. Bidlake, R.S. March and B.W. Kennedy. 2007. Glacier mass-balance fluctuations in the Pacific Northwest and Alaska, USA. Ann. Glaciol., 46, 291-296.

Klok, E.J., W. Greuell and J. Oerlemans. 2003. Temporal and spatial variation of the surface albedo of Morteratschgletscher, Switzerland, as derived from 12 Landsat images. J. Glaciol., 49(167), 491-502.

Kohshima, S. 1987. Glacial biology and biotic communities. In Kawano, S., J.H. Connell and T. Hidaka, eds. Evolution and coadaptation in biotic communities. Kyoto, Kyoto University. Faculty of Science, 77-92.

Kohshima, S., K. Seko and Y. Yoshimura. 1993. Biotic acceleration of glacier melting in Yala Glacier, Langtang region, Nepal Himalaya. IAHS Publ. 218 (Symposium at Kathmandu 1992 Snow and Glacier Hydrology), 309-316.

Painter, T.H., B. Duval, W.H. Thomas, M. Mendez, S. Heintzelman and J. Dozier. 2001. Detection and quantification of snow algae with an airborne imaging spectrometer. Appl. Environ. Microbiol., 67(11), 5267-5272.

Paterson, W.S.B. 1994. The physics of glaciers. Third edition. Oxford, etc., Elsevier.
Schaepman-Strub, G., M.E. Schaepman, T.H. Painter, S. Dangel and J.V. Martonchik. 2006. Reflectance quantities in optical remote sensing - definitions and case studies. Remote Sens. Environ., 103(1), 27-42.

Takeuchi, N. 2001. The altitudinal distribution of snow algae on an Alaska glacier (Gulkana Glacier in the Alaska Range). Hydrol. Process., 15(18), 3447-3459.

Takeuchi, N. 2002a. Optical characteristics of cryoconite (surface dust) on glaciers: the relationship between light absorbency and the property of organic matter contained in the cryoconite. Ann. Glaciol., 34, 409-414.

Takeuchi, N. 2002b. Surface albedo and characteristics of cryoconite (biogenic surface dust) on an Alaska glacier, Gulkana Glacier in the Alaska Range. Bull. Glaciol. Res., 19, 63-70.

Takeuchi, N., S. Kohshima and K. Seko. 2001. Structure, formation, and darkening process of albedo-reducing material (cryoconite) on a Himalayan glacier: a granular algal mat growing on the glacier. Arct. Antarct. Alp. Res., 33(2), 115-122.

Takeuchi, N., Y. Matsuda, A. Sakai and K. Fujita. 2005. A large amount of biogenic surface dust (cryoconite) on a glacier in the Qilian Mountains, China. Bull. Glaciol. Res., 22, 1-8.

Takeuchi, N., R. Dial, S. Kohshima, T. Segawa and J. Uetake. 2006. Spatial distribution and abundance of red snow algae on the Harding Icefield, Alaska derived from a satellite image. Geophys. Res. Lett., 33(21), L21502 (10.1029/2006GL027819.)

Wake, C.P., P.A. Mayewski, Z. Li, J. Han and D. Qin. 1994. Modern eolian dust deposition in central Asia. Tellus, 46B(3), 220-233.

Warren, S.G. 1982. Optical properties of snow. Rev. Geophys., 20(1), 67-89.

Warren, S.G. and W.J. Wiscombe. 1980. A model for the spectral albedo of snow. II. Snow containing atmospheric aerosols. J. Atmos. Sci., 37(12), 2734-2745.

Zeng, Q., M. Cao, X. Feng, F. Liang, X. Chen and W. Sheng. 1984. Study of spectral reflection characteristics of snow, ice and water of northwest China. Sci. Sin. B, 27(6), 647-656. 